Article

\title{
A phenomenological study of military retirees: Reasons for retirement and post-retirement employment in Turkish military staff
}

\author{
Mehmet Özgen ${ }^{1}$, Şule Erdem Tuzlukaya ${ }^{2 *}$, and Ceyhan Çigdemoğlu ${ }^{3}$ \\ ${ }^{1}$ Military Staff; mehmetozgen77@hotmail.com \\ ${ }^{2}$ Atılım University, School of Business; sule.tuzlukaya@atilim.edu.tr \\ ${ }^{3}$ Atılım University, School of Business; ceyhan.cigdemoglu@atilim.edu.tr \\ * Correspondence: sule.tuzlukaya@atilim.edu.tr; Tel.: +90 3125868612
}

Received: 27 December 2019; Accepted: 9 March 2020; Published: 13 March 2020

\begin{abstract}
Recently, an increasing number of retired individuals decide to return to work and seek for post-retirement employment. Although research has already focused on individual and organizational based factors in retirement and post-retirement, the works are limited in some observable settings and well-known professions. The purpose of this study is to delve into the reasons for retirement and post-retirement employment and describe how human capital and social capital takes role in post-retirement employment. A qualitative approach was used with a descriptive phenomenological research design. Ten volunteer military retirees constitute the participants; indepth semi-structured interviews were conducted for data collection. Findings indicate that social and human capital heavily affect the retirement process, and trigger the return to work. The higher the hierarchy of the military staff, the more the social factors are motivating them to post-retirement employment, contrarily. For lower hierarchy, financial issues are more dominant for returning to work. Additionally, the effect of social capital on the post-retirement employment varies according to individual differences such as dependents, beliefs, and passions. The study contributes to theoretical discussions related to retirement and post-retirement employment reasons that can be linked to existing explanations.
\end{abstract}

Keywords: reasons for retirement; reasons for post-retirement employment; human capital; social capital; Turkish military retirees.

JEL codes: J21; J24; J26

\section{Introduction}

Statistics confirm that life expectancy at birth is rising all over the world (Organization for Economic Co-operation and Development, [OECD], 2018). Due to improved living conditions, good sanitation, having better education and advancements in the health industry, people are living longer (OECD, 2018). Naturally, the longer life leads individuals to think and to plan how to satisfy their and their dependents' needs. To fulfill ever-ending needs, individuals feel the necessity of being actively involved in work-life after retirement due to a decrease in; income level, power of purchase, number of resources and financial security in retirement (Yeung \& Zhou, 2017). Related works also mention the sustainability of needs and the necessity of satisfying such needs (Ogums, 2010; Seyfarth, 2009). Yet, regardless of the hierarchy of human needs, individuals may use different attributions and different reasons for post-retirement employment which may later turn to be effective in the process. Besides, different career tracks may offer various opportunities for older workers to continue in retirement jobs and/or to find satisfactory bridge employment (Feldman, 1994). Although some studies 
focused on the retirement and post-retirement employment (Fasbender et al., 2016; Beehr \& Bennett, 2015; Topa et al., 2009; Gobeski \& Beehr, 2009), explaining factors for some particular sectors and contexts is still necessary to support the transition process.

Retirement and post-retirement employment is investigated from a variety of perspectives such as; psychological well-being (Yeung \& Zhou, 2017), facilitating factors in post-retirement (Wöhrmann et al., 2014), impact of culture near retirement (Cottier, 2018), antecedents and consequences of retirement planning and decision-making (Topa et al., 2009), as well as reasons for retirement (Gonzales, 2013). The works commonly mention that individuals may choose to keep on their careers after retirement due to some psychological and sociological reasons. To reveal reasons for retirement and post-retirement employment, also sometimes called bridge employment is still an attractive topic for investigation across different sectors and cultures since the area is nascent and limited in scope for Turkish Military Staff. In the military context, promoting a positive transition and adaptation to retirement may become significant for public health policies. A common transition state that military members usually encountered is returning to civilian employment (Williams, Allen-Collinson, Hokey, \& Evens, 2018). According to Baruch and Quick (2009) veterans feel psychologically underprepared to manage the transition to civilian employment. Williams et al. (2018) also state that military veterans mainly experience difficulties in terms of reconciliation between pre-retirement and civil identities.

Research conducted on the military sector usually focuses on retirement satisfaction and adjustment career adaptability (Ebberwin, Krieshok, Ulven, \& Prosser, 2004; Spiegel \& Shultz, 2003). Limited works, no one from the same contexts, combines reasons for retirement, post-employment, and role of social and human capital on this process. Although studies are focusing on the postretirement in the military, the role of human and social capital effects are not determined qualitatively across the different case of military staff who possess different hierarchal status. Therefore, this study proposes to reveal reasons for retiring, reasons for returning to work (post-retirement employment), and how human and social capitals are effective in post-retirement employment for military staff. Specifically, examining how retirement is attributed to some reasons, exploring major driving forces for post-employment, and the impact of social and human capital in this process can contribute to the field since no work up to now employ all these concepts for a case of Turkish military veterans.

\section{Literature Review}

\subsection{Reasons for retiring}

Retirement is traditionally defined as withdrawal from business or occupation (Atchley, 1982), a steep reduction or cessation of active-working life (Maestas, 2010), or as a recent definition, it is an evolving concept of a social contract (Gonzales, 2013). Individual and organizational motivators are influential in retirement (Gallagher, 2006). Reaching retirement age and being able to receive social security benefits; need to spend quality and more time with the family; fatigue or burn out; wish to change the career, and health issues can be considered as some of the personal motivators. Also, being tired of the work environment; having problems with co-workers; lack of challenge and stressful working conditions can be categorized under the organizational motivators (Neal, 2015; Gallagher, 2006; Venneberg, 2005; Matour \& Prout, 2007). Similarly, Wang and Shultz (2010) pointed out the reasons for retirement and their effect on the whole retirement process. Such reasons can be categorized as individual attributes (demographic characteristics, needs, and values, personality, knowledge, skills, and abilities, attitudes toward retirement, health, and financial circumstances); as job and organizational factors (employment history, job characteristics, job attitudes, career attachment, age stereotypes at work, flexible job options, financial incentives); family factors (family support, marital and dependent care status, marital quality, spouse's working status); and lastly as socio-economic factors, social norms, current economic conditions, future economic trends, social security system and government policies and programs. These factors are all determined as antecedents of the retirement process.

Retirement can also be considered as a transition to a new life stage or kind of a tool that enables the second career. Therefore, retirement should not only be considered as an end, since its ending role 
has been gradually transforming to the proceeding one. Consideration of retirement as a life stage may not only provide a different perspective in terms of its sociological aspect, but also biological life-stages of an individual may be complemented (Luke et al., 2016).

\subsection{Post-retirement employment}

Retirement process does not only include the retirement decision and planning but also it covers post-retirement employment activities (Wang \& Shultz, 2010; Shultz \& Henkens, 2010).Wöhrmann et al. (2013) state that retired individuals may decide to continue their work activities due to many complex factors. For instance, according to Oleksiyenko and Zyczynska-Ciolek (2018), post-retirement employment can both be defined as entering a new job after a planned break and an unplanned return to the labor force due to failure in maintaining a satisfactory living standard. According to Seyfarth (2009) and Wöhrmann et al. (2016) desire to remain mentally active; to stay productive; to learn new things; to mentor others and to create social networks are some of the reasons for return to work. Having a working spouse, missing work socially and mentally, an identity that is tied to still working and wish to stay engaged can be considered as other reasons (Ogums, 2010; Venneberg, 2005). Although certain conceptual debates (Oleksiyenko and Zyczynska-Ciolek, 2018) and controversial ideas exists, such as stating post-retirement employment decision is not related to a sudden reaction towards financial and personal shocks (Wöhrmann et al., 2013), literature regarding return to work after retirement is still growing.

\subsection{Human capital, social capital, and post-retirement employment}

Capital can be classified as material and physical (Bourdieu, 1985). Coleman (1990) pointed out the fundamental and distinctive features of physical, human, and social capital. He proposed that physical and human capital can be observed more easily compared to social capital (Coleman, 1990). In terms of returning to work, human and social capitals are considered vital (Gonzalez, 2013; Platts, et al., 2017). Human capital is described as the knowledge, skills, competencies, and attributes formed in individuals that enable the formation of personal, social, and economic well-being. Daily performed duties and tasks can be regarded as experiences that contribute to human capital. It can also be defined as intellectual property which belongs to an individual and cannot be transferred or exchanged (Moffat, 2017; Kuehn, 2018). In light of the aforementioned definitions, we operationalize the concept of human capital as an individual property that helps to post-retirement employment.

Social capital, on the other hand, is considered as an important and viable asset for the individuals (Inkpen \& Tsang, 2005). It can be described as the accumulation of tangible and intangible resources that are collected through social exchanges (Lee, 2009; Gargiulo \& Benassi, 2000). Discussions on social capital show that there are three elements as; bonds which refer to our close relationships such as family members, close-knit friends, and people who mostly share our values and backgrounds; bridges that point to distant friends, workmates, and associates; and linkages that are networks of connections that individuals may have within society. Thus, social capital may be considered as overall tangible and intangible resources that are gained through social networks (Gargiulo \& Benassi, 2000). It is undeniable that all three have a great effect on people or a group while getting a new position in the society and deciding about other important issues (e.g. spouse, children, friends, employers, coworkers, and so forth). According to Gonzales and Nowell (2016), individuals generally use strong and weak ties to find out employment opportunities. Therefore, social capital that is either gained through strong or weak ties may be seen as crucial in terms of post-retirement employment.

\section{Theoretical Framework}

Although a variety of theories (e.g., role theory, life-course perspective, rational choice theory) provide explanations concerning why and how people decide to return to work, in this article, conceptual discussions are restricted to three fundamental theories; attribution theory, continuity theory, and human motivation theory, since they support the theoretical background more elaborately. Human motivation theory and attribution theory help to understand the motivational and behavioral 
sides. For completing two theories, continuity theory may also shed light on the retirement process as linking post-retirement employment. Attribution theory enables us to explain the world and understand the cause of an event or behavior (Neal, 2015). Accordingly, the shape of behavior generally rests on past experiences. From the retirement point of view, Wang and Shi (2014) stated that the individual's retirement and return to work processes can highly be effected by the accumulation of overall attributes and life experiences. Our study focuses on attribution for exploring why individuals retire and why they choose to return to work.

According to Maslow (1943), the never-ending needs of human are organized based on their priorities. Divided into five steps, the needs commence with physiological - biological needs such as food, water, air, sleep, etc. all provide necessity chemicals for the human body. Without gratifying them, one never thinks of any other needs. Latham and Pinder (2004) pointed out the interest related to Maslow's theory from a variety of perspectives. The deprivation of physiological needs such as hungry and thirsty are not included in the research points of this study because, in theory, we consider that all retirees have already satisfied such basic needs by taking any amount of pension after retirement. The second step is the safety need. Surroundings in peace and calm provide stability for people and they don't want to change their environment (Latham and Pinder, 2004). Confronting with unstable, strange, unfamiliar, dangerous, and uncontrollable situations might be disruptive. Long tenure in the organization might have been set up safety, stable, familiar surroundings for him/her. Wish to maintain a social network, fear of unfamiliar status (retirement process), even having pension lower than working times, etc. cause him/her to feel unsafe and motivate towards the more familiar area. From the perspective of a retiree, who returns to work after retirement, continue to work may primarily just cause such above-mentioned safety reasons (Lim and Feldman, 2003) .

The love needs as the third factor, represents such factors as belonging to society, being a member of any social group, having friends, children, and spouse (Maslow, 1943). After retirement, a retiree may feel entirely isolated, separated, left alone and search for sustaining a good relationship and finally may return to work again. It may play a crucial role and be one of the causes to be in the workplace again. Combining with the safety ones, the love needs especially having a social network can be the main drivers affecting return to work. The esteem need is the fourth element in the hierarchical structure. Retirement might be seen by employees as losing prestige and self-esteem. Cease to work may be equal to the loss being useful to the organization and indirectly to society. Society is regarded as an approval factor for them about usefulness that may reduce the level of respect to retirees (Venneberg, 2005; Seyfarth, 2009). Finally, disturbing circumstances develop them and urge them to take necessary steps on taking a job, returning to work or being unretired. Maslow's final and upper step is the self-actualization. During active life in the workplace, one may not be reached to the pinnacle of the career ladder. Although for an individual it may take many years, achieving selfactualization may provide social connections and relationships (Yeung and Zhou, 2017)

Reasons for retirement and post-employment are also linked to continuity theory, which is based on the principle that middle-aged and older adults tend to preserve their internal and external structures while making choices about themselves and their environment. They prefer to shape themselves and their social environment by using their past life experiences. Continuity is formed by combining change with the past. The meaning of continuity is not to remain unchanged, rather it is prone to changing and re-shape the individual life pattern along with past life experiences (Atchley, 1989). Thus, continuity is a preferred strategy for dealing with aging for a wide variety of reasons. The continuity theory suggests that individuals who have been deeply involved in their work will keep maintaining their daily pursuits by participating in activities which they value highly. The work environment constitutes a possible path to maintain daily pursuits and engage in social interaction with co-workers, seniors, and more business contacts. Newly formed social networks may alleviate the future predicaments brought by retirement and motivate individuals to continue at work rather than retiring. Retirement with bridge employment can be referred to as an opportunity to sustain social networks and familiarities after full-time employment (Von Bonsdorff et al., 2009). On the other hand, it is important to note that continuity theory does not prevent the uncertainty, stress, anxious brought 
by retirement. Instead, maintaining continuity critical for retirees to sustain psychological well-being. Further, retirement should be seen as a new life-style similar to other life stages, not stress creating factor (Wang, 2007). In the meantime, alleviating an unknown retirement process is possible with continuity and possibly with bridge employment. At this point, Kim and Feldman (2000) state that individuals with a high level of human capital are more prone to use the continuity concept in the post-retirement employment process.

To sum up, post-retirement employment is emerging and expanding as an important issue (Fasbender et al., 2013). Most individuals choose to work even after retirement or later in their life span (Maestas, 2010). The literature related to post-retirement is also thriving and tackled from many different perspectives. In this study, we will delve into the details of military participants' responses to explore and describe the reasons for retiring and returning to work for the military sector, in Turkey which is mainly overlooked. Specifically, the study seeks answers to the following research questions as 1) what are the reasons for retirement and post-employment for a case of Turkish military veterans in? And 2) how do social and human capital factors affect Turkish military veterans to come back to the workplace after retirement?

\section{Methodology}

This study utilizes an interpretive methodology with a qualitative approach. The specific method used in this study is descriptive phenomenological research design. According to Giorgi (as cited in Stones, 1988), the operative word in phenomenological research is "describe"; so researchers aim to describe the phenomenon as accurately as possible, refraining from any pre-given framework, but remaining true to the facts.

\subsection{Participants}

Since the study proposes to reveal reasons for retirement and post-retirement employment of military veterans, they were selected based on a purposive sampling technique. Based on two criteria for the participants were selected; first, participants were expected to be retired from the military sector entitled to have a governmental pension, second, all participants should return to work after retirement and receive a salary or earn income at their present job. All participants were a volunteer.

There is a hierarchical structure in the military; there are officers $(\mathrm{O})$, non-commissioned officer (NC), specialist sergeants (S), and enlisted personal. Officers are at the top position of hierarchy and generally do managerial works in the military. Their education levels are equal to graduate or university degree (tertiary degree or more). Non-commissioned officers are generally at the middlelevel managerial status and some of them have a technical position (some of them are educated on Vocational Military High School). Their education levels are equal to the college level. Specialist sergeants are at the bottom of the managerial tier and chosen among high school graduates willingly to enter the military job. After a short training duration, they are assigned as a specialist in the military. Whatever their education level, they can go further for education and improve their knowledge while working in the military. So, definitions that are mentioned above are just some requirements about the education level of the participants. Table 1 provides some demographic information about the participants.

The selected ten military veterans had just been retired from military and given honorable service in Armed Forces. They had experienced retirement for a while and then returned to work for some reason. The majority of participants in this study were not acquainted with the researchers. One of the researchers is military staff and his close friend suggested researchers to these participants. On the first contact with potential participants, the researcher talked about the purpose of the research and informed them about contest and anonymity. Then asked whether they were interested in contributing to or not. 
Table 1. Demographic Information about Participants

\begin{tabular}{|c|c|c|c|c|c|c|c|c|c|c|}
\hline $\mathbf{P}$ & P1 & $\mathbf{P 2}$ & P3 & $\mathbf{P 4}$ & P5 & P6 & P7 & P8 & P9 & P10 \\
\hline Hierarchy & $\mathrm{NC}$ & $S$ & $\mathrm{NC}$ & $\mathrm{NC}$ & $\mathrm{O}$ & $S$ & $\mathrm{O}$ & $\mathrm{NC}$ & $S$ & $\mathrm{O}$ \\
\hline Gender & Male & Male & Male & Male & Male & Male & Male & Male & Male & Male \\
\hline Age & 47 & 51 & 44 & 45 & 57 & 48 & 54 & 57 & 49 & 53 \\
\hline $\begin{array}{l}\text { Years at } \\
\text { work }\end{array}$ & 25 & 21 & 24 & 25 & 20 & 25 & 29 & 23 & 21 & 29 \\
\hline $\begin{array}{l}\text { Education } \\
\text { Level }\end{array}$ & BS & HS & BS & BS & MS & BS & BS & BS & HS & MS \\
\hline $\begin{array}{l}\text { Income in } \\
\text { Military }\end{array}$ & $\approx 1200 \$$ & $\approx 900 \$$ & $\approx 1200 \$$ & $\approx 1200 \$$ & $\approx 1800 \$$ & $\approx 900 \$$ & $\approx 1800 \$$ & $\approx 1200 \$$ & $\approx 900 \$$ & $\approx 1800 \$$ \\
\hline $\begin{array}{l}\text { Retirement } \\
\text { Salary }\end{array}$ & $\approx 700 \$$ & $\approx 500 \$$ & $\approx 700 \$$ & $\approx 700 \$$ & $\approx 1200 \$$ & $\approx 500 \$$ & $\approx 1200 \$$ & $\approx 700 \$$ & $\approx 500 \$$ & $\approx 1200 \$$ \\
\hline $\begin{array}{l}\text { Marital } \\
\text { Status }\end{array}$ & M & $\mathrm{M}$ & $\mathrm{M}$ & M & M & $\mathrm{M}$ & M & M & M & M \\
\hline $\begin{array}{l}\text { Working } \\
\text { Spouse }\end{array}$ & NW & NW & NW & NW & NW & NW & NW & W & NW & $\mathrm{R}$ \\
\hline $\begin{array}{l}\text { Number of } \\
\text { Children }\end{array}$ & 0 & 3 & 3 & 5 & 1 & 2 & 3 & 2 & 2 & 2 \\
\hline
\end{tabular}

Note: P: Participants; HS: High School; BS :Bachelor of Science; MS: Master of Science, M: Married; $\approx$ : Approximately NW: Not working; W: Working; R: Retired.

\subsection{Study context}

Before the year 1999, it was mandatory to serve 25-years to be retired in Turkey. From 1979 to 1999, retirement age increased from 44 to 60 based on the regulation of the social security institute. Then, with regulations in 2008, the retirement age would remain the same, 60, till 2035. After that, it would gradually increase to 65 for both males and females in 2044. Such regulations are not surprising due to the continuing trend in longer life expectancy. In line with the increase in the average life expectancy of OECD member countries, Turkish people's life expectancy has also increased from 73.7 ages to 78 in 2007 (OECD; 2016). In the study context, the years of working for retirement may change across the fields, for example; for military staff, the retirement age is 56, while for academicians it is 67 in state higher education institutions (Pension Fund Law of the Republic of Turkey, Issue: 7235). Based on given law and regulations, the age of retirement varies for different sectors. After a certain working time, in all sectors, individuals stop working and they deserve to receive an amount of pension. However, retirement for civilians has some differences when compared to the retirement of individuals in the military.

In the civilian workforce, retirement usually occurs around 60 years of age after working for an organization for 30 years or more. However, in the military, most service members retire before the age of 50 after working a minimum of 20 years. The term "early retirement" in the civil sector is regular retirement in the military (Hunt, 2007). In the study context, retirement age also has been changed and gradually increased to a point according to serving time for each individual in the year 1999. Formerly, it was possible to retire after serving 20-year. This means that military retirees could find any other job and enter the workforce again at middle-age. However, 20-year of serving is not enough to retire with pension today even though the time-span gives certain privileges without pension. If anyone wants to continue to work out of the military, he/she should quit the career job and enter the civilian workforce again without a pension. The concept of retirement and post-retirement process in the military sector needs more elaborations in the study context because of the potential to shed light on reasons beyond the decisions.

Furthermore, as one of the researchers is from the military sector, his own experiences direct us to explore the reasons and attributions of military staff too. Hunt (2007) stated that in qualitative studies, the researcher is the prime instrument for data collection. Consequently, "the researcher's 
perspective and experiences as affected by the research settings become itself as important to the research as the subjects and conditions understudy" (p.40).

\subsection{Data collection; interviews}

Interviews were conducted with participants who consent to share their views. The date and time for the interviews were agreed upon consensus. Semi-structured interviews were conducted. Each interview session lasted around twenty-thirty minutes. Using probe questions during interviews enabled to fully understand the reasons for retirement and returning to work. The interview questions were constructed based on the purpose of the study, experiences of the researchers, and related literature. For face and content validity, two experts from the field examined the interview questions. And based on the comments the questions are revised. The interview sessions were all tape-recorded. Participants were probed to make more explanations for elaborating their answers and asked to justify their responses to clarify any ambiguity. The interviews also helped researchers to understand the exact meanings under their phrases to explore their lines of thinking. All interviews were conducted in the native language to avoid losing or escaping any crucial details.

\subsection{Data analysis}

Data obtained from the interviews were transcribed verbatim. All interviews and transcripts were uploaded to a qualitative data analysis program called Nvivo Plus 11 Trial-Version. Qualitative data analysis was employed for the transcribed data and the researchers used a descriptive content analysis technique (Fraenkel, Wallen, \& Hyun, 2012). Participants' responses were categorized based on the coding of investigated concepts. The main categories were created based on the research questions; many themes have emerged from the responses. These themes were categorized below the "reasons for retiring" "reasons for returning work", and "the impact of social and human capital". While organizing findings, first-order interpretations were provided as excerpts, second-order interpretations were given as what the pure data implies for researchers (themes and categories), and also, third-order interpretations were provided to link the concepts to the literature and theories as suggested by Neuman (2014).

\subsection{Reliability}

Interviews took place mostly like a mutual conversation to create a confidential environment among researchers and participants. The interview questions were asked respectively, but in the case of needs, some of them were skipped according to the course of the interview. When necessary, some probe questions were directed to participants for digging the conversation to get more details. To establish inter-rater agreement or reliability of coding, three researchers analyzed the data independently, compared their generated codes and reexamined the data to resolve the discrepancies and then reach consensus. Confidentiality of the study was explained to participants before each interview session so that they could feel relax and comfort. So, they could provide details of their experiences, feelings, emotions, and even private lives. This enabled the researcher to get more valuable information about them. Their answers are assumed to be sincere and accurate. Since the researcher is a military person and has some common experiences, he was able to delve into details when necessary. For translations of words from native language to English is also checked by all researchers for consensus.

\subsection{Ethical issues of the study}

All the interviews were conducted with the consent form and related permissions from the Institutional Review Board (IRB) were taken for data collection. All participants voluntarily participated in the study through a written consent form. During the interviews, the participants are informed to be able to quit from the talk whenever they want, or if they want to skip a question. 
Through this, issues regarding ethics in research, such as protection of the participants from harm, and confidentiality were assured as suggested by Neuman (2014).

\section{Findings}

The findings are organized based on the categories concerning; reasons for retiring from a career job, reasons for returning to work after retirement, and the role of social and human capital in postretirement employment. Below each category, the related themes are provided.

\subsection{Reasons for retiring from a career job}

Reasons for retiring from a career job may generally be based on a variety of factors. In terms of our study, some of the participants stated that their retirement was forced, and some stated they were voluntarily retired. Table 2 indicates the common reasons for retiring.

Table 2: Reasons for Retiring

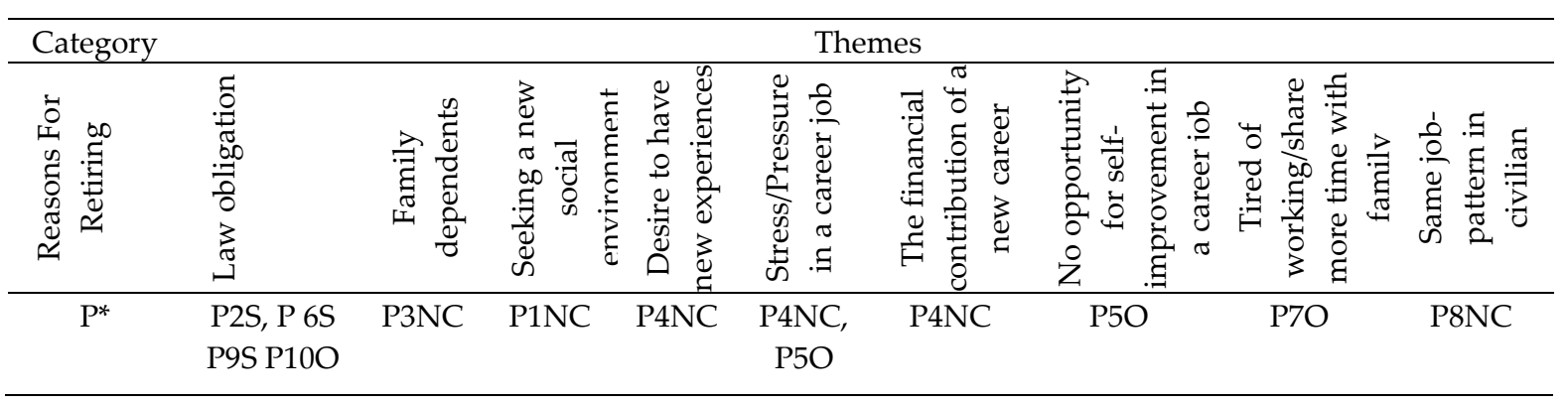

Note: P: Participants, grey highlighted participants attribute retirement as being forced, the rest as $a$ volunteer.

As seen from Table 2, all specialist sergeants (S) attributed that they were forced to retire, and they all stated it was a law obligation. Additionally, they stated that they would work more if the system lets them do. All non-commissioned officers (NC) stated they were volunteered for retirement. Their reasons are about family dependents, desire for new social environment and experiences, the stress in career and the option of finding a similar job in the civilian environment because of their capabilities. For officers $(\mathrm{O})$ being forced or volunteered was different. The reason for the forced one was law obligation. He stated that "I want to work more, but, the government made some regulation on retirement law. It is reduced from 32 years to $28^{\prime \prime}$. For one of the officers $(\mathrm{O})$ who was volunteered to be retired, the reasons were being tired and need for sharing more time with family. Other officers stressed no options for self-improvement as the reason for retirement, despite stating to be forced for retirement. For the other one, law obligation was the cause of retirement.

When comparing the reasons of our participants with the reported reasons in the literature, we noticed that tiredness/burned-out/stress in a career job, desire to spend more time with family, wish to change career paths, seeking for a new environment were the same. Whereas the themes: retirement law and availability of the same job in the civil sector were specific to this context. Compared to other groups, NCO more focused on financial reasons as a cause of retirement.

About half of ten participants indicated they were obliged to retire due to a variety of reasons while the other half said that their retirements were planned and they retired voluntarily. Also, most mentioned reasons for retirement were; a stressful environment in the military and financial advantages in another career. All participants experienced their retirement differently. When asked what they did in the 'honeymoon stage' their responses were related to how they retire from a career job. If they were forced to retire, and soon after retirement, P2, P6, and P9 struggled to enter any job to earn income and make ends needs, financial problems. They attributed their careers as bad experiences that reflect how they felt, lived, and even anger. Two participants (P4 and P8) mentioned financial problems as reasons for retiring. They were confident that their income would not drop at a lower level than the salary brought by a career job. They were able to compare their prospective and career job in terms of financial issues, and thus they were motivated to retire. At the same time, if retired; 
they would do the same job in the civil sector. If retirement was not an obligation caused by the law, mostly they thought not to experience any financial difficulties after retirement (P1, P7). Retirement for them was an event which should occur in regular when its time comes.

\subsection{Reasons for returning to work after retirement}

Table 3 indicates the major themes mentioned as impacting on returning to work. As seen, two major issues; financial and social reasons are very powerful in the post-retirement employment of the participants. The reasons for returning to work are in line with the literature; learn new things/pursue own desires, needing extra income/not ready for retirement, desire to interact with society, etc. However, one finding was different; the desire to belong to society/workplace/ a job to go was mentioned by one NCO. That reason is not about financial issues, it is rather concerning participants' motivation to belong to a society, network, and to produce more to the sustainability of society by employment.

Table 3. Reasons for post-retirement employment

\begin{tabular}{|c|c|c|c|c|c|c|c|c|c|c|}
\hline $\begin{array}{l}\text { Emerging themes for } \\
\text { post-retirement employment }\end{array}$ & $\begin{array}{l}\text { P1 } \\
\text { NC }\end{array}$ & $\begin{array}{c}\mathrm{P} 2 \\
\mathrm{~S}\end{array}$ & $\begin{array}{l}\text { P3 } \\
\text { NC }\end{array}$ & $\begin{array}{l}\text { P4 } \\
\text { NC }\end{array}$ & $\begin{array}{l}\text { P5 } \\
\text { O }\end{array}$ & $\begin{array}{c}\text { P6 } \\
\text { S }\end{array}$ & $\begin{array}{l}\text { P7 } \\
\text { O }\end{array}$ & $\begin{array}{l}\text { P8 } \\
\text { NC }\end{array}$ & $\begin{array}{c}\text { P9 } \\
\text { S }\end{array}$ & $\begin{array}{c}\text { P10 } \\
\text { O }\end{array}$ \\
\hline Financial Reasons & & & & & & & & & & \\
\hline a. Having any income/earn money & & $\sqrt{ }$ & $\sqrt{ }$ & & & $\sqrt{ }$ & & & $\sqrt{ }$ & \\
\hline $\begin{array}{l}\text { b. Having better income/improve the } \\
\text { monetary status }\end{array}$ & & & & $\sqrt{ }$ & & & & $\sqrt{ }$ & & $\sqrt{ }$ \\
\hline Social Reasons & & & & & & & & & & \\
\hline $\begin{array}{l}\text { a.Desire to belong a place or society / } \\
\text { have a job to go }\end{array}$ & & & & $\sqrt{ }$ & $\sqrt{ }$ & & $\sqrt{ }$ & & & \\
\hline $\begin{array}{c}\text { b. Wish to form social relations/social } \\
\text { network }\end{array}$ & & & $\sqrt{ }$ & & & & & $\sqrt{ }$ & & \\
\hline $\begin{array}{l}\text { c. Wish to be productive / learn new } \\
\text { things / useful to society }\end{array}$ & $\sqrt{ }$ & & & & & & & & & \\
\hline
\end{tabular}

As apparent from Table 3, all specialists (S) motivation to return to work is about having any money, whereas, for NCs, better income is more mentioned. Officers less stress financial issues as a reason for returning work. This is possible because of their retirement pensions and higher salaries while working in the military. One interesting finding is that none of the specialists mentions social issues as a reason for returning to work. This may be attributed to hierarch of needs, without feeling safe with the necessary money, the participants do not consider social issues for returning work. Social desires are perceived to be more about self-actualization. Participants (P1, P7, P8) who did not experience financial predicaments demonstrated social reasons for retiring such as seeking a new environment, new social networks, desire to self-improvement, and be useful to society more. Social reasons for them dominated financial reasons or push beyond to second place in reasons list.

\subsection{Role of human and social capital in post-retirement employment}

For specialists, the only human capital is their experiences gained in the military sector. They don't have the social capital to support their post-retirement too. As shown in Table 4, post-retirement employment was unplanned for them and their present works are less prestigious jobs when compared to others. One may attribute it to their human capital since according to Vermeer et al. (2016:161), lower educated individuals "do not have access to a large stock of human capital".

Compared to S, NC seems to have more human capital especially about their education, and they state the impact of their education on post-retirement. Officers both mention experiences and education as a human capital impacting on finding a new job after retirement from the military. Based on the findings, we can briefly state that the participants' reasons for retirement and returning work 
are affected by their position in the military. Officers in this study stated that they did not search for a job after retirement. On the contrary, their friends invited them for a job and gave an offer working together. However, all specialists in this study had financial difficulties after retirement and they had to search for a job by lonely after retirement. They did whatever they found as a job.

Table 4. Social and Human Capital Effects

\begin{tabular}{|c|c|c|c|c|}
\hline $\mathrm{P}^{\prime} \mathrm{s}$ & Main Reason & Social Capital Elements & Human Capital & Present job \\
\hline $\begin{array}{l}\mathrm{P} 1 \\
\mathrm{NC}\end{array}$ & $\begin{array}{l}\text { Planned - } \\
\text { Social } \\
\text { (routine) }\end{array}$ & $\begin{array}{l}\text { Spouse, Parenting, Friends } \\
\text { Adaptation to a new society } \\
\text { Desire to become social } \\
\text { Desire to beneficial to society } \\
\text { (Bonds, bridges, and linkages) }\end{array}$ & $\begin{array}{l}\text { Education on business } \\
\text { and accounting } \\
\text { Military Experience }\end{array}$ & $\begin{array}{l}\text { Real estate } \\
\text { counselor }\end{array}$ \\
\hline $\begin{array}{c}\mathrm{P} 2 \\
\mathrm{~S}\end{array}$ & $\begin{array}{l}\text { Unplanned- } \\
\text { Financial }\end{array}$ & Parenting, Spouse (Bonds) & $\begin{array}{l}\text { Vocational education } \\
\text { Experience as a } \\
\text { maintenance person in } \\
\text { the military }\end{array}$ & $\begin{array}{l}\text { Worker in } \\
\text { construction }\end{array}$ \\
\hline $\begin{array}{l}\mathrm{P} 3 \\
\mathrm{NC}\end{array}$ & $\begin{array}{l}\text { In time- Social } \\
\text { (family) }\end{array}$ & $\begin{array}{l}\text { Parenting, Spouse } \\
\text { Family Dependents } \\
\text { (Bonds and bridges) }\end{array}$ & $\begin{array}{l}\text { Vocational education } \\
\text { Experience as the same } \\
\text { field works in the military }\end{array}$ & IT company \\
\hline $\begin{array}{l}\mathrm{P} 4 \\
\mathrm{NC}\end{array}$ & $\begin{array}{l}\text { In time- Social } \\
\quad \text { (stress) }\end{array}$ & $\begin{array}{l}\text { Parenting, Spouse } \\
\text { Friends (Bonds and Bridges) }\end{array}$ & $\begin{array}{l}\text { Vocational education } \\
\text { Experience as the same } \\
\text { field works in the military }\end{array}$ & $\begin{array}{l}\text { Aviation } \\
\text { company }\end{array}$ \\
\hline $\begin{array}{c}\mathrm{P} 5 \\
\mathrm{O}\end{array}$ & $\begin{array}{l}\text { In time-Social } \\
\text { (pressure- } \\
\text { self- } \\
\text { enhancement) }\end{array}$ & $\begin{array}{l}\text { Parenting, Spouse, Friends } \\
\text { Social reasons for society } \\
\text { (Bonds, bridges, and linkages) }\end{array}$ & $\begin{array}{c}\text { Education-Engineer } \\
\text { Foreign Language skills }\end{array}$ & Instructor \\
\hline $\begin{array}{l}\text { P6 } \\
\text { S }\end{array}$ & $\begin{array}{l}\text { Unplanned- } \\
\text { Financial }\end{array}$ & Not clearly stated & Not related qualifications & $\begin{array}{l}\text { Employer- } \\
\text { Employee }\end{array}$ \\
\hline $\begin{array}{l}\mathrm{P} 7 \\
\mathrm{O}\end{array}$ & $\begin{array}{l}\text { In time-Social } \\
\text { (family) }\end{array}$ & $\begin{array}{c}\text { Parenting, Spouse, Friends } \\
\text { Social reasons for society } \\
\text { (Bonds, bridges, and linkages) }\end{array}$ & $\begin{array}{l}\text { Management skills } \\
\text { Experiences in military }\end{array}$ & $\begin{array}{l}\text { Insurance } \\
\text { Company }\end{array}$ \\
\hline $\begin{array}{l}\mathrm{P} 8 \\
\mathrm{NC}\end{array}$ & $\begin{array}{l}\text { In time-Social } \\
\text { (same job) }\end{array}$ & $\begin{array}{c}\text { Parenting } \\
\text { Spouse-Working } \\
\text { Friends (Bonds and bridges) }\end{array}$ & $\begin{array}{l}\text { English Language } \\
\text { education and } \\
\text { experiences in the } \\
\text { military (directorship) }\end{array}$ & $\begin{array}{l}\text { Instructor- } \\
\text { Manager }\end{array}$ \\
\hline $\begin{array}{c}\text { P9 } \\
\text { S }\end{array}$ & $\begin{array}{l}\text { Unplanned- } \\
\text { Financial }\end{array}$ & Parenting, Spouse, (Bonds) & Military Experiences & $\begin{array}{l}\text { Security } \\
\text { Guard }\end{array}$ \\
\hline $\begin{array}{c}\mathrm{P} 10 \\
\mathrm{O}\end{array}$ & $\begin{array}{l}\text { Unplanned- } \\
\text { Financial }\end{array}$ & $\begin{array}{c}\text { Spouses-Retired, Parenting } \\
\text { Father role, Social pressure from } \\
\text { society,(Bonds, bridges, and } \\
\text { linkages) }\end{array}$ & Military Experiences & $\begin{array}{l}\text { Manager in } \\
\text { Elec.com. }\end{array}$ \\
\hline
\end{tabular}

All participants were asked if they had any social factors on their post-retirement employment. Based on the demographics questions such as; age, marital status, having working/not working spouse, all participants are married. However, just two of all had working spouses while one of all participants has retired spouse. The places of a working spouse as a theme in this research are not 
evaluated because they did not mention it as a reason for their returning to work. In one case, one of all participants mentioned that his age is too early to stop working. Participants not experiencing financial difficulties are searching for new roles in a new society. They desire to belong to a group or society. To be in society gives individuals some responsibilities to be accepted by others. Similarly, one officer participant mentioned and put differences between working and not working individuals. $\mathrm{He}$ narrated this difference with his example. He mentioned that working status in society takes respectful reactions from society members.

\section{Discussion and Conclusion}

\subsection{Evaluation of findings and theoretical implications}

Present work provides an overall look and a number of findings related to the reasons for retirement, post-retirement employment, and the effect of human and social capital on return to work for Turkish military veterans. The leading themes emerged as the main reasons for retirement are; retirement law effects, financial needs (urgent satisfaction), and need for belonging to a society/group/place. The findings support the idea of Gallagher (2006) and Neal (2015) stating that both organizational and individual factors are influential in the retirement process.

When delving into details, it is apparent that participants' demographic characteristics such as; education level, family factors, marital status, and dependent care status, spouse's working status are important for reasons of retirement. These findings are congruent with the literature (Neal, 2015; Williams et. al, 2018). Although the findings obtain support from previous literature, there is a number of divergent findings. For example, in the literature of post-retirement employment, most of the studies are focused on participants whose ages are generally above 65 (Ogums, 2012; Gonzales \& Nowell, 2017; Fasbender et al., 2017), contrarily, in this particular study, the participants are all relatively younger. When compared to the civilian workforce, the age of retirement is young for military staff; they may retire at almost the age of $45 \mathrm{~s}$, either voluntarily or to be forced. So, different from the literature this study provides insights in terms of focusing on younger-aged retirement and postretirement employment. Another contribution may be related to the career job positions of the retirees.Related literature focuses on retirees mostly did not consider their positions in their preretirement occupations. Our findings reveal that previous career job positions within the organization (ranking, position within the hierarchy in the organization) may be seen as one of the fundamental issues for post-retirement employment. For our study context, it is shown that participants' position in the hierarchy is an important factor in the post-retirement employment and career.

Additionally, individual attributes such as; values, personality, skills, age stereotypes at work are also shaping participants' reasons for retirement. These findings are consistent with Wang and Shultz (2010) stating the impact of these and more factors on the retirement process. Furthermore, based on our empirical evidence, we can state that the intensity of these factors changes across the different types of military staff. Thus, characteristics of the military job influence post-retirement reasons for military personnel. We also noticed that expectations from retirement influence their post-retirement experiences, military staff holding more realistic expectations have a better adjustment to a postretirement job. We confirmed that retirement from the military is often motivated not only by economic considerations (McNeil \& Giffen, 1967) but also by some social and psychological needs (Spiegel \& Shultz, 2003).

Financial factors are the most important motivators of military retirees for a new job according to the participants. Gallagher (2006) indicated that participants in his study faced a variety of reasons for returning to work or barriers to retirement such as financial issues and some social motivators. Some participants did not prepare themselves for retirement during their active career years. Their spend habits prevented them from saving enough for inactive years, retirement. Or, they did earn just enough money for the expenditure of family dependents and so they couldn't find any chance to save enough money for the future. On this issue, Ogums (2010) also stated in his study that spending habits which prevent savings during the accumulation years. As a result, they work longer to compensate for 
inadequate savings for their respective future and family needs. According to Maslow (1943), these findings are also meaningful. He stated that human has potentially physiological needs which should be urgently satisfied at first step such as food, water, shelter and so forth. After that, another step such as safety needs can be recognized or thinkable for humans. Participants in this study who talked about financial reasons for their returning to work are thoroughly in trouble in terms of monetary issues. Another theme put forwarded by participants in the social motivators. Again, the basic needs of human-directed them to employment after retirement. After satisfying physiological needs, social needs start to surface respectively. Safety, self-esteem, love, and self-actualization follow in Human Motivation Theory (Maslow, 1943).

Participants who did not mention financial factors as returning to work are motivated by social reasons. Venneberg (2005) purported also social findings from his study. In his study, feeling more to contribute, having a working spouse, missing to work socially, an identity that is tied to still working, and wish to stay engaged, do something new are major findings playing major roles for postretirement employment. These findings are consistent with our findings such as pass on experiences to others, social pressures from society, being useful to society, desire to learn new things. In the meantime, participants in this study stated some different factors motivating them to work again. One participant indicated his father's role as affecting him. His son sees him as a working father and this affected him to return. Also, some participants show a continuity role for their returning to work. Maintaining continuity is critical for retirees to sustain psychological wellbeing. Further, retirement should be seen as a new life-style similar to other life stages, not stress creating factor (Wang, 2007). The theory of continuity is based on the principle that middle-aged and older adults tend to preserve their internal and external structures (in this study as father role or society role) while making choices about themselves and their environment. They prefer to shape themselves and their social environment by using their past life experiences. These findings are consistent with the literature.

When we come to the concept of human capital, we observed that all participants retired from the military reflect a strictly framed society. Furthermore, findings also point out that human capital emerges as an antecedent of employment after retirement. However, their positions were differed based on their education level. Status in military personnel ranged from high to low as officers, noncommissioned officers, and specialist sergeants. While officers are generally at higher status with managing roles, non-commissioned officers are at the middle level of management. Specialist sergeants are at the bottom hierarchy in the military. Their education levels reflect this hierarchy and their roles in military affect experiences which will also affect their civilian role in society. Naturally, education level is a determinant factor for each individual and increase in possibilities of finding any role in society easily. Moreover, when reasons for retirement and reason for post-employment are compared, it is evident that there is an association among statements. The ones attributing retirement as forced and law obligation stressed more on the need for money. Regarding family dependents theme, contradictory findings existed in literature. In this work, the participant (P3) stated the importance of family dependents and attributed that his retirement was a volunteer. This finding is consistent with Shultz et al. (1998). However, Wang and Shi (2014:224) pointed out that such retired individuals are "perceived as being forced". Such contradictions might easily be explained to different perceptions of the individuals, as also Shultz et al (1998) did. However, we also would like to underline the importance of contextual and occupational differences and to suggest for investigation in future studies. For another participant who planned the retirement and attributed to his reason as seek for excitement, the reason for post-employment was about social and self-actualization needs rather than monetary issues (P1). We can state that participants' reasons for retirement and post-employment are consistent.

Social reasons are also presented; findings on social reasons affecting the decision on returning to work vary for each participant. While one gives desiring to be useful to society as a social reason, the other gives former colleagues' effectiveness on his decision on working again. However, reasons repeated more than once are related to searching for a new social network or environment. Belonging to society is a major and strong motivator for them in their post-retirement employment. Being 
beneficial for society, according to literature is one of the fundamental antecedents of post-retirement employment (Lockenhoff et al., 2009). This finding is appropriate for our participants but only for NCs and Os. Special sergeants' reasons for return to work are more related to family and financial issues. However, since sergeants within our study did not want to retire but instead they are forced, so they preferred to continue even the context was too stressful, that contradict the literature which states that stressful pre-retirement job may lead the individual towards early retirement (Wang and Shi, 2014). Besides, having a working spouse and parenting are additional factors that can also come together under social capital formation. So, working spouses may allow extension of a social network of the individual in terms of it may increase the referral opportunities (Gonzales \& Nowell, 2016). Parenting, in the same way, increases the social network. Social reasons given by participants in this study are correlated with both Maslow (1943) and Atchley (1989). As human needs are satisfied, another need especially social one comes out. Using previous experiences and re-shaping them, participants reflect a continuity role in society whatever their positions or occupations.

Being nearly at middle-ages, having family dependents, and ongoing needs are some causes deterring militaries to quit the job without pension. Another predicament can be said that there are few job opportunities in the civil sector similar to the military work concept. Theoretically, military retirees are having experiences very differently after retirement. Similar to other countries, so much strict environment exists in a military context in this study. There are few job-fields in the civil sector similar to the military work atmosphere. Some of our participants have also mentioned this use for the post-retirement process. After retirement, it is unsurprising that military society can live hard times on adaptation to civil life and on finding a new job opportunity based on their hierarchy in the military. Figure 1 summarizes all findings and their match with the theoretical framework used in this study.

Figure 1. A summary of reasons for retirement and reasons for returning work across the framework.

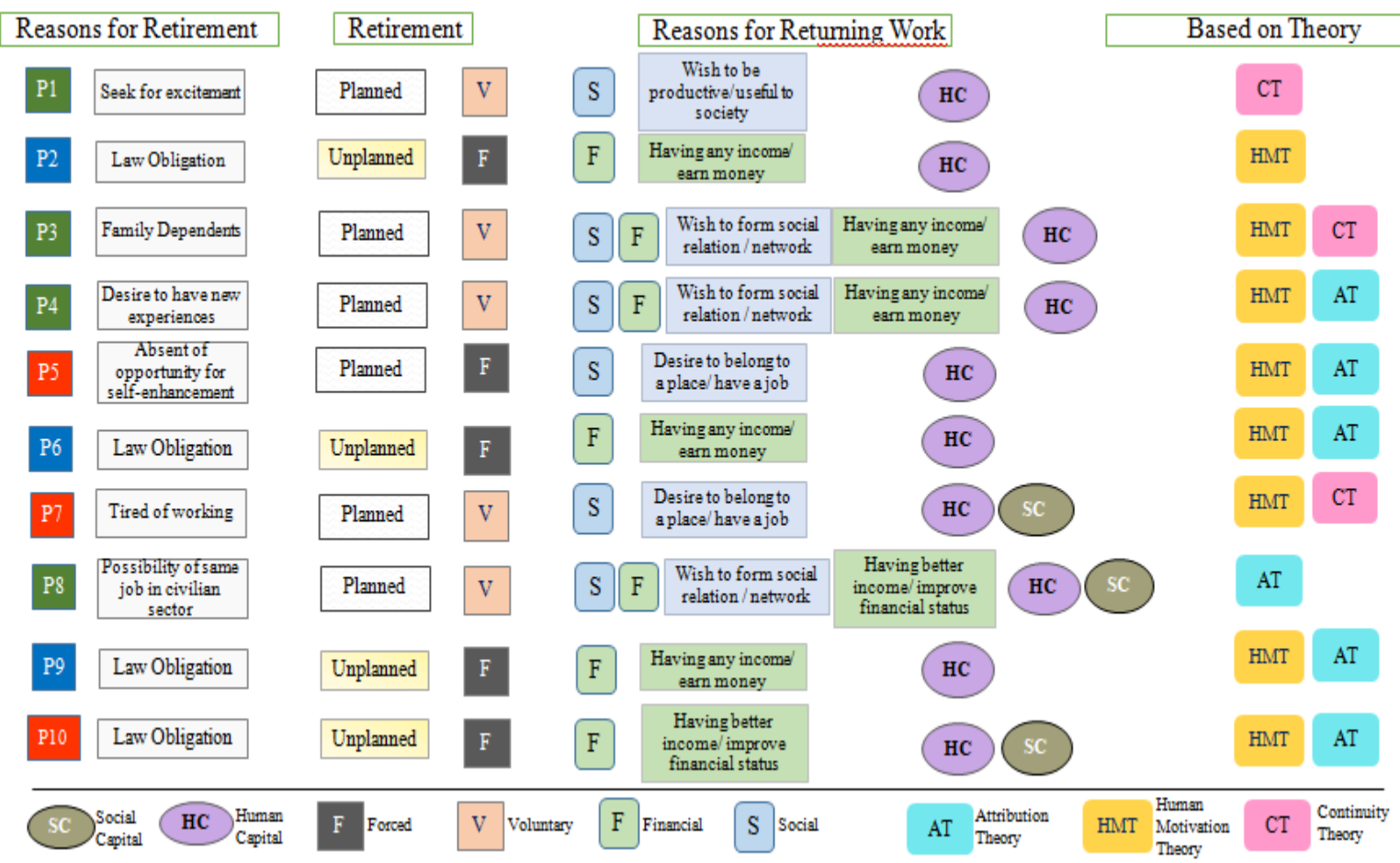

To conclude, participants' reasons for retirement are not as varying as provided in the literature, human capital is more effective in their post-retirement process than social capital. Human motivation theory finds a strong place in participants' responses as their reasons for retirement and the new job. This shows explicitly that human needs and satisfaction are endless. Unlike animals motivated by the simple/basic needs such as finding food, people in common society never halt to search new desire 
and put new goals to the front and also as urgent physiological needs are satisfied, new needs come out and the individual goes on the next step (Maslow, 1943).

\subsection{Practical implications}

Human resources still receive the utmost attention from contemporary organizations since they are important and hard to substitute. The present study offers some useful implications for managers. First, military organizations may focus on and generate some procedures in terms of contributing to the physiological readiness of the retirees and their transition to civil life. Also, in general, the organizations that retirees participate in their post-retirement career should consider the adjustment of military retirees through the application of such human resource practices. Second, military organizations also gather information from retirees related to their professional experience and may find a kind of mechanism for allowing them to contribute. Additionally, in a post-retirement career, human resources and organizational psychologists should pay attention, especially to early-retired military personnel, since they are forced for retirement.

\subsection{Limitations and suggestions for future research}

One of the limitations of this study might be the number of participants since the data is collected from only ten participants that may restrict the findings. Conducting only interviews as a data collection tool may also be attributed as a limitation. The sampling technique, researchers' experiences in conducting interviews might also be perceived as a limitation. Additionally, the research related to post-retirement employment is still a developing field (Bal et al., 2015). The findings are limited to this context and are not aiming to make generalizations. Furthermore, the collected data is limited to only three different statuses in military personnel, for different status the provided reasons might be different. When findings are replicated with different samples, more grounded empirical realities may emerge about the military sector.

For future studies, the following suggestions may be provided. First of all, there are no researches related to the impacts of actors/retirees on the process yet. However, take the change agent role, might be effective on how might be the influence of retirees on the process. Especially, the social network of the retirees is suggested to be analyzed in order to understand through which ties their post-retirement employment has occurred. Similarly, analyzing their social network will also be helpful to understand for determining dimensions of their social capital. Other suggestive research questions might be related to the transition period through which longitudinal studies can be applied for evaluating pre and post-retirement experiences of the individuals. Besides, using multiple research methods is also suggested. Through more data, this kind of works about military staff may find practical implications for policymakers. Some formal military programs can be established to increase awareness of military staff concerning retirement and support them for the transition process. Some special programs are specifically necessary for specialist sergeants since they seem to be more vulnerable in this transition stage, for the particular context. To sum up, this study contributes to literature providing empirical evidence about reasons for retirement and post-employment along with the impact of social and human capital on this process for the military sector.

Author Contributions: M.O. and C.C. conceived of the presented idea. M.O., C.C., and S.T. reviewed the literature. S.T. developed the theoretical background. C.C contributed the research design. M.O. collected the data and analyzed the data. C.C. and S.T. contributed to reliability. M.O. and C.C. decided on the drawings. S.T. supported discussion and conclusion. M.O. prepared the manuscript, C.C and S.T. edited the manuscript

Funding: This research received no external funding

Acknowledgments: This study is produced from first author's unpublished master thesis.

Conflicts of Interest: The authors declare no conflict of interest. 


\section{References}

Atchley, R. C. (1982). Retirement as a social institution. Annual review of sociology, 8(1), 263-287.

Atchley, R.C. (1989). A continuity theory of aging. Gerontologist, 29, 183-190.

Bal, P. M. (2015). Sustainable careers: enabling older workers to continue working through individualized work arrangements. In Handbook of research on sustainable careers. Edward Elgar Publishing.

Baruch, Y., \& Quick, J.C. (2007). Understanding second careers: lessons from a study of U.S Navy Admirals. Human Resource Management. 46 (4):471-491

Beehr, T. A., \& Bennett, M. M., (2015). Working after retirement: Features of Bridge employment and research directions. Work, Aging and Retirement, 1:112-128

Bourdieu, P. (1985). The forms of capital. In J. G. Richardson (Ed.),. New York: Greenwood: Handbook of theory and research for the sociology of education: 241-258.

Coleman, J. S. (1990). Foundations of Social Theory. The Belknap Press Of Harvard.

Cottier, L. (2018). Culture, financial constraints, and retirement decision. Labour Economics. 53: 128-145

Ebberwin, C. A., Krieshok, T. S., Ulven, J. C., \& Prosser, E. C. (2004). Voices in transition: Lessons on career adaptability. The Career Development Quarterly, 52, 292-308.

Fasbender, U., Wang, M., Voltmer, J. and Deller, J. 2016. The meaning of work for Post-retirement employment decisions. Work, Aging and Retirement, 2(1):12-23.

Fasbender, U., Deller J., Wang M., Wiernik B.M.(2013). Deciding whether to work after retirement: The role of the psychological experience of aging. Journal of Vocational Behavior 84(2014), 215-224.

Feldman, D. G. (1994). The decision to retire early: A review and conceptualization. Academy of Management Review, 19: 285-311.

Fraenkel, J. R., Wallen, N. E., \& Hyun, H. H. (2011). How to design and evaluate research in education. New York: McGraw-Hill Humanities/Social Sciences/Languages.

Gallagher, K. F. (2006). Preretirement process and its effect on the workplace (Order No. 3241665). Available from ProQuest Dissertations \& Theses Global. (305289311).

Gargiulo, M. and Benassi, M. (2000) Trapped in Your Own Net? Network Cohesion,

Structural Holes, and the Adaptations of Social Capital. Organization Science, 11, 183-196. http://dx.doi.org/10.1287/orsc.11.2.183.12514

Gobeski, K. T., \& Beehr, T. A. (2009). How retirees work: Predictors of different types of bridge employment. Journal of Organizational Behavior: The International Journal of Industrial, Occupational and Organizational Psychology and Behavior, 30(3), 401-425.

Gonzales, E., \& Nowell, W. B. (2016). Social capital and unretirement: Exploring the bonding, bridging, and linking aspects of social relationships. Research on Aging, 39(10), 1100-1117.

Gonzales, G. E. (2013). An examination on un-retirement: Retirees returning to work (Order No. 3593208). Available from ProQuest Dissertations \& Theses Global. (1438181057).

Hunt, J. E. (2007). Military retirement transition as learning (Order No. 3272154). Available from ProQuest Dissertations \& Theses Global. (304815536).

Inkpen, A. C., \& Tsang, E. W. K. (2005). Social capital, networks, and knowledge transfer. Academy of Management Review, 30(1), 146-165. doi: 10.5465/amr.2005.15281445.

Kim,S. and Feldman, D.C.(2000). Working In Retirement: The Antecedents of Bridge Employment and Its Consequences for Quality of Life in Retirement. Academy of Management Journal. 4 (6). 1105-1210.

Kuehn, D.(2018). Human Capital in the Twenty First Century. The European Journal of Comparative Economics Vol. 15, n. 1, pp. 3-9. dx.doi.org/10.25428/1824-2979/201801-3-9

Lee,R.2009. Social capital and business and management: Setting a Research Agenda. International Journal of Management Reviews 11(3):247-273.

Lim,V.K.G \& Feldman,D. (2003). The impact of time structure and time usage on willingness to retire and accept bridge employment, International Journal of Human Resource Management, 14(7), 1178-1191.

Luke, J., Mcllveen, P., \& Perera, H. N. (2016). A thematic analysis of career adaptability in retirees who return to work. Frontiers in psychology, 7, 193.

Löckenhoff, C. E., Terracciano, A., \& Costa Jr, P. T. (2009). Five-factor model personality traits and the retirement transition: Longitudinal and cross-sectional associations. Psychology and aging, 24(3), 722.

Maestas, N. (2010). Back to work expectations and realizations of work after retirement. Journal of Human Resources, $45(3), 718-748$. 
Maslow, A.H. (1943). A theory of human motivation. Psychological Review, 50, 370-396.

McNeil, J. S., \& Giffen, M. B. (1967). Military retirement: the retirement syndrome. American Journal of Psychiatry, 123(7), 848-854.

Matour, S., \& Prout, M. F. (2006). Psychological Implications of Retirement in the 21st Century. Journal of Financial Service Professionals / January 2007.57-63

Moffat, V.R.(2017). Human Capital as Intellectual Property? Non-Competes and the Limits of IP Protection. Akron Law Review, Vol. 50 [2017], Iss. 4, Art. 7.

Neal, S. G. (2015). Factors that influence retired executives in higher education to reenter the workforce (Order No. 10003437). Available from ProQuest Dissertations \& Theses Global. (1761843936).

Neuman, W. L. (2014). Social Research Methods: Qualitative and Quantitative Approaches: Pearson New International Edition. Pearson Education Limited.

OECD (2018), The Organization for Economic Co-operation and Development . Life expectancy at birth (indicator). doi: 10.1787/27e0fc9d-en (Accessed on 18 October 2018).

Ogums, R. U. (2010). Attitudes and beliefs toward post-retirement employment: A grounded theory study (Order No. 3406676). Available from ProQuest Dissertations \& Theses Global. (288226769).

Oleksiyenko, O., \& Życzyńska-Ciołek, D. (2018). Structural determinants of workforce participation after retirement in Poland. Journal of Population Aging, 11(1), 83-103.

Platts, G.L. et al. (2017). Returns to Work after Retirement: A prospective Study of Unretirement in the UK. Ageing \& Society, Cambridge UniversityPress.p.1-26.Doi: 10.1017/So144689X17000885.

Seyfarth, M. L. (2009). An exploratory study on factors of post-retirement employment (Order No. 3359036). Available from ProQuest Dissertations \& Theses Global. (305163959).

Schultz, K. S., \& Henkens, K. 2010. Introduction to the changing nature of retirement: An international perspective. International Journal of Manpower, 265-270.

Shultz, K. S., Morton, K. R., \& Weckerle, J. R. (1998). The influence of push and pull factors on voluntary and involuntary early retirees' retirement decision and adjustment. Journal of vocational behavior, 53(1), 45-57.

Spiegel, P. E., \& Shultz, K. S. (2003). The influence of preretirement planning and transferability of skills on naval officers' retirement satisfaction and adjustment. Military psychology, 15(4), 285-307.

Stones, C. R. (1988). Research: Toward a phenomenological praxis. In Kruger, D. (Ed.), An introduction to phenomenological psychology (2nd ed, pp. 141-156). Cape Town, South Africa: Juta.

Topa, G., Moriano, J. A., Depolo, M., Alcover, C. M., \& Morales, J. F. (2009). Antecedents and consequences of retirement planning and decision-making: A meta-analysis and model. Journal of Vocational Behavior, 75(1), 38-55.

Vigoda-Gadot, E., Baruch, Y., \& Grimland, S. (2010). Career transitions: An empirical examination of the second career of military retirees. Public Personnel Management, 39(4), 379-404.

Venneberg, D. L. (2005). Experiences of retirees and their decision to return to the workforce: implications for organizations, The (Doctoral dissertation, Colorado State University. Libraries).

Vermeer, N., Mastrogiacomo, M., \& Van Soest, A. (2016). Demanding occupations and the retirement age. Labour Economics, 43, 159-170.

Vigoda-Gadot E., Baruch, Y., \& Grimland, S. (2010). Career transitions: An Empirical Examination of second career of military retirees. Public Personnel Manage, 39 (4):379-404

Von Bonsdorff, M.E. et al. (2009). The Choice between Retirement and Bridge Employment: A Continuity Theory and Life Course Perspective. Int'l. J. Aging and Human Development, Vol. 69(2) 79-100, 2009

Wang, M. (2007). Profiling Retirees in the Retirement Transition and Adjustment Process: Examining the Longitudinal Change Patterns of Retirees' Psychological Well-Being. Journal of Applied Psychology 2007, Vol. 92, No. 2, 455-474.

Wang, M., \& Shultz, K. S. (2010). Employee retirement: A review and recommendations for future investigation. Journal of Management, 36(1), 172-206.

Wang, M., \& Shi, J. (2014). Psychological research on retirement. Annual review of psychology, 65, 209-233.

Williams, R., Allen-Collinson, J., Hockey, J., \& Evans, A. (2018). 'You're just chopped off at the end': Retired servicemen's identity work struggles in the military to civilian transition. Sociological Research Online, 23(4), 812-829.

Wöhrmann, A.M., Fasbender, U., Deller, J. (2016). Using Work Values to Predict Post-Retirement Work Intentions. Career Development Quarterly. 64(2), 98-113. DOI: 10.1002/cdq.12044. 
Wöhrmann, A.M., Deller,J., Wang, M. (2014). A Mixed Approach to post-retirement career planning. Journal of Vocational Behavior. 84:307-317.

Wöhrmann, A.M., Deller, J., \& Wang, M. (2013). Outcome expectations and work design characteristics in postretirement work planning. Journal of Vocational Behaviour, 83:219-228.

Yeung, D. Y., \& Zhou, X. (2017). Planning for Retirement: Longitudinal Effect on Retirement Resources and Postretirement Well-being. Frontiers in Psychology, 8, 1300.

(C) 2020 by the authors. This article is an open-access article distributed under the terms and conditions of the Creative Commons Attribution (CC BY) license (http://creativecommons.org/licenses/by/4.0/). 